\title{
The Effectiveness of Discovery-Based Virtual Laboratory Learning to Improve Student Science Process Skills
}

\author{
W. Nirmala \\ Depertment of Chemistry Education, Universitas Darussalam Ambon, Ambon, Indonesia \\ e-mail:wa.nirmala92@gmail.com
}

S. Darmawati

Depertment of Chemistry Education, Universitas Darussalam Ambon, Ambon, Indonesia e-mail: sitidarmawati35@gmail.com

\section{A R T I C L E I N F O \\ Article history: \\ 25 December 2020 \\ Received in revised form \\ 01 January 2021 \\ Accepted 25 January 2021 \\ Available online 03 February \\ 2021

\begin{tabular}{l}
\hline Kata Kunci: \\
Laboratorium $\quad$ Virtual, \\
Keterampilan Proses Sains
\end{tabular} \\ Keterampilan Proses Sains \\ Keywords: \\ Virtual Laboratory, Science \\ Process Skills}

\begin{abstract}
A B S T R A K
Kondisi laboratorium, sarana dan prasarana yang tidak memadai menjadi kendala utama kurangnya kegiatan praktikum. Tujuan penelitian ini adalah untuk menguji keefektifan pembelajaran laboratorium virtual berbasis penemuan dalam meningkatkan keterampilan proses sains siswa. Jenis penelitian ini adalah penelitian one-group-pretestpostest design. Populasi dan sampel yang diambil adalah mahasiswa yang mengambil mata kuliah Kimia Dasar II. Metode pengumpulan data dilakukan secara dokumenter dan analisis datanya berupa penghitungan persentase peningkatan keterampilan proses sains dan kriteria keefektifan N-Gain. Hasil yang diperoleh adalah pembelajaran laboratorium virtual berbasis penemuan yang berhasil meningkatkan keterampilan proses sains siswa. Keterampilan proses sains dengan kriteria tinggi meningkat sebesar 91\% dan pada kategori sedang sebesar 9\%. Berdasarkan perhitungan N-Gain pembelajaran laboratorium virtual berbasis discovery diperoleh rata-rata persentase efektivitas sebesar $66 \%$ sehingga dapat disimpulkan pembelajaran laboratorium virtual berbasis penemuan cukup efektif dalam meningkatkan keterampilan proses sains siswa. Melalui pembelajaran laboratorium virtual berbasis discovery, keterampilan proses sains siswa lebih mudah dikembangkan sehingga pembelajaran menjadi lebih bermakna.
\end{abstract}

\begin{abstract}
A B S T R A C T
The inadequate condition of the laboratory, facilities, and infrastructure is the main obstacle to the lack of practicum activities. The purpose of this study was to examine the effectiveness of discovery-based virtual laboratory learning in improving science process skills of students. This type of research is a one-group-pretest-postest design research. Population and sample taken were students who took Basic Chemistry II course. The data collection method was carried out in a documentary manner and data analysis was in the form of calculating the percentage increase in science process skills and the criteria for the effectiveness of N-Gain. The results obtained were discovery-based virtual laboratory learning that succeeded in improving students' science process skills. Science process skills with high criteria increased by $91 \%$ and in the moderate category by $9 \%$. Based on the N-Gain calculation, discovery-based virtual laboratory learning obtained an average percentage of effectiveness of $66 \%$ so it can be concluded that discovery-based virtual laboratory learning is quite effective in improving student science process skills. Through discovery-based virtual laboratory learning, student science process skills are more easily developed so that learning becomes more meaningful.
\end{abstract}

\section{Introduction}

Chemistry is a part of science whose concept is abstract and must be absorbed by students in a relatively limited time. Chemical material is very conceptual so that it requires students to understand in a meaningful way (Ferdian, Maryam, \& Selamat, 2018; Lubis \& Ikhsan, 2015). Chemistry learning is not only a collection of knowledge such as facts, concepts or principles, but also a process of discovery (Jayadiningrat, 2017; Nazalin \& Muhtadi, 2016). Chemistry cannot be carried out purely theoretically. Therefore, it requires a laboratory as a place to process learning through the practicum method. This method aims to hone thoughts and as a way for students to become more active. Practicum is a part of teaching that aims to give students the opportunity to test what is gained from theory and practic (Rina Mirdayanti \& Murni, 2017). Practicum is a learning method that can provide real experiences to students in building their own knowledge so that learning becomes more meaningful. Practicum is providing experiences that can be used with the aim of increasing understanding of the material. The goal will be achieved when participants are given the experience to feel natural phenomena with all their senses (touch, sight, smell, taste, and hearing). These activities are discovery and verification (Sari, Gunawan, \& Harjono, 2017). 
The current condition is the lack of inadequate infrastructure. This problem also occurs in FKIP, Universitas Darussalam Ambon. Based on the results of preliminary observations, it was found that the laboratory had inadequate facilities and infrastructure. Limited funds and facilities generally become the main obstacle to the lack of practicum activities in chemistry learning. Laboratory infrastructure is a part that is often the main obstacle (Wulandari, Herlita, \& Nurmiyati, 2020). Procurement of infrastructure is not only a matter of cost and time, but also the continuation of fairly complex management, especially for universities with limited resources (land, workers, funds and time) (Maksum, 2020). Activities in the laboratory are one of chemistry lessons besides class teaching which allows students to build their own experiences (Manikowati \& Iskandar, 2018; Tatli, 2010). According to Sastrawijaya (1988), practical work in chemistry can be divided into several types, namely (1) practicum by students, (2) practicum which is demonstrated to students, (3) practicum which is not shown directly, but through props, and (4) practicum which is only told by teachers or books. Experiments can be carried out with two media, namely real or virtual. Learning with real and virtual media has the same goal, namely that students can explore the nature of science, develop collaborative abilities, be critical and scientific, and to understand them conceptually.

One solution to provide a more meaningful learning experience with limited facilities and infrastructure is to do virtual laboratory learning. By using virtual media, the concept is conveyed in accordance with the demands of the learning objectives. The virtual laboratory is an alternative model in overcoming the problem of practicum implementation (Abdjul, Ntobuo, \& Payu, 2019; S. M. Dewi, Gunawan, Harjono, Susilawati, \& Herayanti, 2020). The virtual laboratory is an ICT-based learning process that can be used as an alternative solution for learning with the practicum method (Manikowati \& Iskandar, 2018). The virtual laboratory is a modeling, simulation, and information technology to create interactive learning between lecturers and students (Khairudin, Triatmaja, Istanto, \& Azman, 2019; Masril, Hidayat, 2019). Virtual laboratory learning is one of the superior products of advances in information technology and laboratories. Based on research results by (Hermansyah, Gunawan, \& Herayanti, 2017) and Aşiksoy \& Islek 2017), it is obtained an illustration that students who have low abilities at the beginning will increase after doing virtual laboratory learning. Their creative thinking ability becomes higher. This is in line with research conducted by Dewa, Maria Ursula Jawa Mukin, \& Oktavina Pandango (2020) stated that delivery with virtual laboratory media can make students more innovative, creative, and effective. The main principle in this media is to increase the efficiency and effectiveness of learning in terms of using time, funds, and facilities because it is done calmly, quickly, and precisely. With the implementation of a virtual laboratory, the building and chemical equipment are converted into computers and software. In addition, the advantages of virtual laboratories are that they can minimize the abuse of chemical equipment, overcome the possible dangers posed by real laboratories, and create opportunities to conduct experiments for free (Khairudin et al., 2019; Tatli, 2010).

The benefits of virtual labs in learning are as follows: 1) reducing time constraints, if there is not enough time to teach all students in the laboratory until they understand; 2) reducing geographic barriers, if there are students who live far from school; 3) economical, does not require laboratory buildings, tools and materials as in conventional laboratories; 4) improve the quality of the experiment because it allows it to be repeated clarifying doubts in laboratory measurements; 5) increasing the effectiveness of learning because students will spend more and more time doing lab work repeatedly; and 6) increase security and safety because it does not interact with real tools and materials (Ferreira, 2012). The benefits of virtual laboratories are to make it easier for students to connect theoretical and practical aspects without writing tools (Rizal, Adam, \& Susilawati, 2018; Yusuf \& Widyaningsih, 2020). To make the use of virtual labs effective in the laboratory, an invention learning model is applied in the process or what is called discovery-based virtual laboratory. In this model, the teacher gives students the freedom to discover for themselves because they can better understand what they are learning. This learning model emphasizes students to seek and find their own subject matter through various activities. In the discovery learning process, students can use mental processes, such as observing, questioning, classifying, making hypotheses, measuring, and concluding, to find concepts (Masril, Hidayat, 2019). In general, process skills refer to cognitive processes or thought processes. Process skills are skills used when learning science (Atmojo, 2012; Marnita, 2013). Science process skills include intellectual, psychomotor, and affective skills related to science learning in all its aspects. Skills in the cognitive domain include comparing, communicating, inferring, predicting, applying, measuring, evaluating. The skills of observing, classifying, manipulating, experimenting, and measuring are related to the psychomotor domain, whereas affective is related to enjoying the aesthetics of discovery, experience, deferring judgment, persevering when difficulties and ambiguity. These process skills assist in advancing their knowledge in science and other disciplines (Marnita, 2013; Rahayuni, 2016).

In virtual laboratory activities, students can be trained in several science process skills, such as observing, classifying, measuring, communicating, interpreting data, and making conclusions so as to make chemistry learning more interesting and fun. This is relevant to previous research conducted by Sari et al (2017) which states that the results of the $\mathrm{N}$-Gain test in the experimental class show that there is a significant increase 
in students' science process skills because the stages and media in virtual practicum discovery-based virtual practicum learning provide opportunities for students to develop students' science process skills. This is relevant to previous research conducted by Gunawan, Harjono, Hermansyah, \& Herayanti (2019) who concluded that guided inquiry models through virtual laboratories had a significant effect on science process skills. The average science process skills of the experimental group of students were higher than the control group in each indicator. In addition, research conducted by Yusuf \& Widyaningsih (2018) stated that the use of virtual lab media can develop science process skills and student perceptions are very good about the learning carried out. Based on the analysis of science process skills as a whole, the mean score was $81.95 \%$ or very good category. This shows that students are skilled in formulating problems, expressing provisional presumptions, identifying variables, classifying data, interpreting data, formulating models, connecting data, and making conclusions.

The objective of this research is to examine the effectiveness of discovery-based virtual laboratory learning in improving science process skills of FKIP students, Universitas Darussalam Ambon. With this research, it is hoped that discovery-based virtual laboratory learning can make it easier for students to learn so that they can improve their science process skills.

\section{Method}

This type of research is a one-group-pretest-posttest design research. The population in this study were FKIP students of Universitas Darussalam Ambon which consisted of four departments, namely Mathematics Education, Physics Education, Chemistry Education, and Biology Education. The sampling technique used was purposive sampling technique, also known as consideration sampling. The samples taken were FKIP students of Universitas Darussalam Ambon, who took the Basic Chemistry course II for 2019/2020 academic year. The research variables consisted of the independent variable $(\mathrm{X})$ and the dependent variable $(\mathrm{Y})$. In this study, the independent variable $(\mathrm{X})$ is virtual laboratory learning and the dependent variable $(\mathrm{Y})$ is the student's science process skills.

The data collection method was carried out in a documentary manner and data analysis was in the form of calculating the percentage level of learning outcomes related to the subject concerned, data analysis regarding the improvement of science process skills and student responses to the implementation of the discovery-based virtual laboratory. Furthermore, data processing was carried out by: 1) analysis of early science process skills collected from the pre-test data; 2) the analysis of the improvement of science process skills is based on the post test data according to the science process skills assessment criteria (E. P. Dewi, Suyatna, Abdurrahman, \& Ertikanto, 2017), 3) Observation sheet based on a questionnaire; and 4) the effectiveness of discovery-based virtual laboratory learning on Chemical Equilibrium material and calculated based on normalized gain.

Table 1. Science Process Skills Assessment Criteria

\begin{tabular}{cc}
\hline Category & The percentage of mean score $(\%)$ \\
\hline High & $66,67 \% \leq \mathrm{X}$ \\
Moderate & $33,33 \% \leq \mathrm{X}<66,67 \%$ \\
Low & $\mathrm{X}<33,33 \%$ \\
\hline
\end{tabular}

Table 2. N-Gain Effectiveness Category

\begin{tabular}{cc}
\hline Category & Persentage (\%) \\
\hline Effective & $>76$ \\
Enough & $56-75$ \\
Less & $40-55$ \\
Ineffective & $<40$ \\
\hline
\end{tabular}

\section{Result and Discussion}

This research was conducted to see the increase in science process skills and its effectiveness after being given Invention-Based Virtual Laboratory Learning. Learning is carried out online using the Google Meet and Whatsapp Group applications. The science process skills seen is the basic skills which includes observing, classifying, communicating, predicting, and concluding (Rezba, 1995). The initial of science process skills was obtained from a pre-test. The questions given were in the form of ability tests on previously taught material and were closely related to chemical equilibrium material. The pre-test results obtained can be seen in Table 3 . 
Table 3. Pre-test Results of Science Process Skills

\begin{tabular}{ccc}
\hline Pre-test & Results & Criteria \\
\hline Minimal value & 24 & Low \\
Maximum value & 68 & High \\
Mean & 38,55 & Moderate \\
\hline
\end{tabular}

The pre-test results obtained were divided into three criteria, namely high, medium and low. Based on Table 3, the average initial science process skills possessed by students is in the medium criteria with mean score of 38.55. The initial of science process skills obtained from the overall pre-test data can be seen in Figure 1.

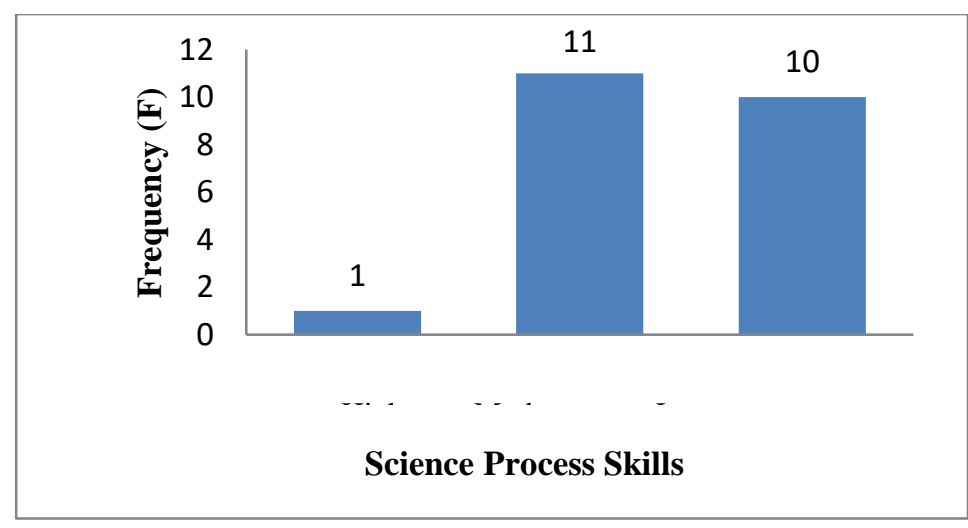

Figure 1. Pre-test results of Science Process Skills

Based on Figure 1, the initial of science process skills was more dominated by moderate criteria as many as 11 students and low criteria as many as 10 students, while the high criteria only achieved by 1 student. Discovery-based virtual laboratory learning is a modification of the virtual practicum learning model with the discovery learning model. This learning is applied online to the Chemical Equilibrium material. The post-test results obtained after the application of discovery-based virtual laboratory learning can be seen in Table 4.

Table 4. Post-test Results of Science Process Skills

\begin{tabular}{ccc}
\hline Pre-Test & Results & Criteria \\
\hline Minimal value & 60 & Moderate \\
Maximum value & 92 & High \\
\hline Mean & $\mathbf{7 9 , 2 7}$ & High \\
\hline
\end{tabular}

Based on Table 4, the mean post-test score obtained by students after doing discovery-based virtual laboratory learning was 79.27. This value shows that the level of science process skills possessed by students is in the high category. The overall post-test result data from 22 students is presented in Figure 2.

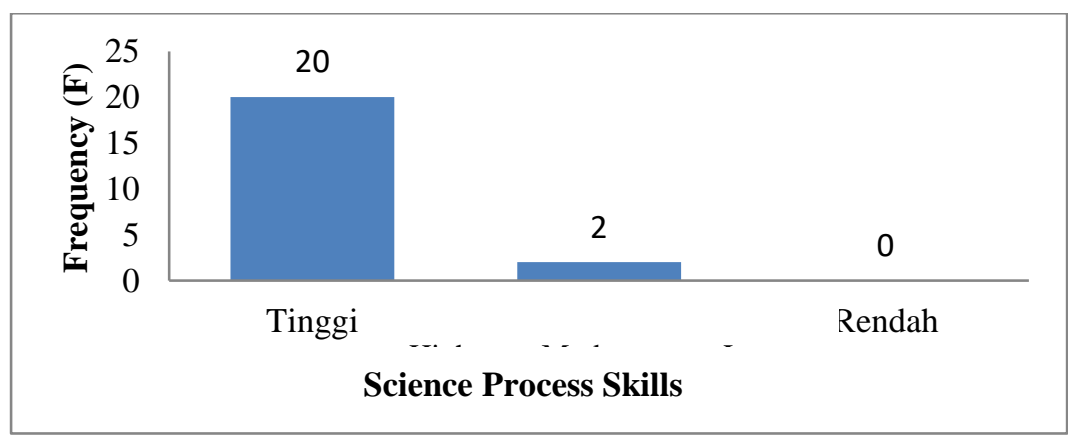

Figure 2. Post-test results of Science Process Skills 
Students' science process skills after being applied to discovery-based virtual laboratory learning have increased and can be seen in Figure 2. A total of 20 students have high and 2 students have moderate criteria. The percentage increase in science process skills of students after the implementation of learning is presented in Table 5 below.

Table 5. Percentage of Increase in Science Process Skills

\begin{tabular}{ccccc}
\hline & \multicolumn{5}{c}{ Percentage of Increase in Science Process Skills } \\
\cline { 2 - 5 } Criteria & \multicolumn{2}{c}{ Pre-test } & F & Post-Test \\
\cline { 2 - 5 } & 1 & 5 & 20 & 91 \\
\hline High & 11 & 50 & 2 & 9 \\
Moderate & 10 & 45 & 0 & 0 \\
Low & $\mathbf{2 2}$ & $\mathbf{1 0 0}$ & $\mathbf{2 2}$ & $\mathbf{1 0 0}$ \\
\hline Total & & & & \\
\hline
\end{tabular}

Discovery-based virtual laboratory learning has succeeded in improving the science process skills of students. This can be seen clearly in Table 5, the science process skills for the high category increased from 5\% to $91 \%, 50 \%$ of students who had science process skills in the moderate category decreased to $9 \%$, and the low category science process skills decreased to $0 \%$.

In addition to pre-test and post-test data, science process skills were also seen from the response questionnaire given to students after conducting discovery-based virtual laboratory learning. The indicator of science process skills is included in the response questionnaire which aims to determine the responses to the process skills possessed by students. Furthermore, students' science process skills based on a questionnaire are presented in Table 6.

Table 6. Percentage of science process skills based on questionnaire

\begin{tabular}{lcccc}
\hline \multirow{2}{*}{ No } & Indicator & Avarage & Agree & Percentage (\%) \\
\cline { 4 - 5 } & & & 81.82 & Disagree \\
\hline $\mathbf{2}$ & Observe & 3.2 & 90.91 & 9.18 \\
$\mathbf{3}$ & Classify & 3.3 & 90.91 & 9.09 \\
$\mathbf{4}$ & Communicate & 3.3 & 100 & 0 \\
$\mathbf{5}$ & Predict & 3.5 & 100 & 0 \\
\hline
\end{tabular}

Based on Table 6 , the average respondent agrees $(81.82 \%)$ by making virtual observations, as many as $90.91 \%$ agree that it is easy to classify and communicate, and as many as $100 \%$ agree that it is easy to predict and conclude after doing discovery-based virtual learning.

Assessment of the effectiveness of discovery-based virtual laboratory learning can be seen based on the $\mathrm{N}$-Gain calculation. This calculation uses two criteria, namely the N-Gain criteria in general and the criteria for effectiveness. The results of the N-Gain calculation based on pre-test and post-test data are presented in Table 7 and the results of the effectiveness of discovery-based virtual laboratory learning are presented in Table 8 .

Table 7. Results of N-Gain Calculation

\begin{tabular}{cccc}
\hline Category & Frequency $(\mathbf{F})$ & Avarage of N-Gain & Criteria \\
\hline \multirow{3}{*}{ N-Gain } & 14 & 0.72 & High \\
& 8 & 0.56 & Moderate \\
& 0 & 0 & Low \\
\hline & Mean & $\mathbf{0 . 7}$ & High \\
\hline
\end{tabular}

Based on Table 7, students who obtained N-Gain with high criteria were 14 people and moderate criteria were 8 students. From the calculation results, the average N-Gain obtained after carrying out the discovery-based virtual laboratory learning process is in the high category with an average value of 0.7 . 
Table 8. The Effectiveness of Discovery-Based Virtual Laboratory Learning

\begin{tabular}{cccc}
\hline Category & Frequency $(\mathbf{F})$ & Avarage of Percentage (\%) & Criteria \\
\hline \multirow{3}{*}{ Effectiveness } & 3 & 79.19 & Effective \\
& 17 & 66.25 & Enough \\
& 2 & 48.68 & Less \\
& 0 & 0 & Ineffective \\
\hline
\end{tabular}

The success rate of discovery-based virtual laboratory learning applied to FKIP students of Universitas Darussalam Ambon, can be seen from the effectiveness of the learning carried out. Based on Table 8, discoverybased virtual laboratory learning obtained an average percentage value of $66 \%$. Based on the effectiveness criteria, the average percentage is classified as enough effective.

The observation sheet used in this study was a student response questionnaire to learning consisting of indicators of appraisal interest and responses to the learning process. This questionnaire was filled in by 22 respondents. The results of the percentage of student responses to learning are presented in Table 9.

Table 9. Percentage of Student Responses to Learning

\begin{tabular}{|c|c|c|c|}
\hline \multirow{2}{*}{ No } & \multirow{2}{*}{ Statement } & \multicolumn{2}{|c|}{ Percentage of Response (\%) } \\
\hline & & Agree & Disagree \\
\hline 1 & $\begin{array}{l}\text { Discovery-based virtual laboratory learning is a new and exciting } \\
\text { lesson for me }\end{array}$ & 95.45 & 4.55 \\
\hline 2 & I like to make observations virtually & 81.82 & 18.18 \\
\hline 3 & $\begin{array}{l}\text { Virtual laboratory makes my knowledge increase in predicting an } \\
\text { experiment }\end{array}$ & 100 & 0 \\
\hline 4 & $\begin{array}{l}\text { Practicum with virtual laboratory, made me able to answer the } \\
\text { questions. }\end{array}$ & 90.91 & 9.09 \\
\hline 5 & $\begin{array}{l}\text { Learning with a virtual laboratory helps me to conclude an } \\
\text { experiment }\end{array}$ & 100 & 0 \\
\hline 6 & $\begin{array}{l}\text { The opportunity to express ideas to be more in learning with virtual } \\
\text { laboratories, }\end{array}$ & 90.91 & 9.09 \\
\hline 7 & $\begin{array}{l}\text { By implementing a virtual laboratory, the material of chemical } \\
\text { equilibrium becomes easier to understand }\end{array}$ & 90.91 & 9.09 \\
\hline 8 & $\begin{array}{l}\text { I find it easier to compile a classification concept after doing virtual } \\
\text { laboratory learning }\end{array}$ & 90.91 & 9.09 \\
\hline 9 & $\begin{array}{l}\text { The instructions for using the virtual laboratory are easy to } \\
\text { understand }\end{array}$ & 95.45 & 4.55 \\
\hline 10 & $\begin{array}{l}\text { In my opinion, all chemistry lab materials should be done in a virtual } \\
\text { laboratory. }\end{array}$ & 68.18 & 31.82 \\
\hline
\end{tabular}

Based on Table 9, it can be concluded that students give good responses to virtual laboratory learning. As many as $95.45 \%$ of students are interested in studying chemical equilibrium with discovery-based virtual laboratories. Then, $81.82 \%$ said they liked making virtual observations, as many as $100 \%$ of students considered virtual laboratories to increase knowledge in predicting and concluding an experiment, and as many as $90.91 \%$ said they were able to answer questions and express ideas after using discovery-based virtual laboratories. Then, a number of $90.91 \%$ of students stated that it was easy to understand the material of chemical equilibrium by using a virtual laboratory. Meanwhile, $90.91 \%$ considered it easy to classify reactions after using discoverybased virtual laboratories. In general, students easily understand the instructions for using a discovery-based virtual laboratory application with a percentage of $95.45 \%$ so that it is easy to apply. In addition, the majority $(68.18 \%)$ agreed to use virtual laboratories for all practicum materials.

Initial science process skills were obtained from the pre-test in the form of a description test. The description test given aims to find out that the scientific work process actually occurs and students understand the concept well. Therefore, in each subject of the test, students are required to state reasons or explain the answer, so that it can be interpreted that students master the concepts and process skills. The pre-test given consisted of five questions on the material that had been taught previously, namely chemical equilibrium. Ability tests are given based on indicators of basic science process skills recommended by The American Association for the Advancement of Science (AAAS) in the form of observing, classifying, predicting, communicating, and concluding skills. Based on Figure 1, students' initial science process skills are dominated by low criteria as 
many as 10 people, moderate criteria are 11 people, and high criteria are only achieved by 1 person. So, the average value obtained is 38.55 which is in the medium criteria. The diversity of early science process skills acquired can be caused by student characteristics. FKIP students of Universitas Darussalam Ambon's, have different cognitive, social and cultural abilities. In addition, the personality of each student in the form of different attitudes, feelings and interests is also influential. Therefore, the pre-test data that inform early science process skills also appear mixed.

Discovery-based virtual laboratory learning is a modification of virtual practicum learning model with discovery learning model. Discovery learning model is very appropriate to be used in virtual practicum process because students are required to seek and find their own knowledge during the learning process (Patandung, 2017; Putrayasa, Syahruddin, \& Mergunayasa, 2014; Sunismi, 2015). In addition, the use of virtual laboratories can also improve generic science skills (Dewa et al., 2020) and train students in applying scientific processes including stating problems, formulating hypotheses, collecting data, testing hypotheses, and concluding. This research is also supported by (Gunawan et al., 2019), which states that students have the opportunity to improve science process skills through investigative activities such as observation, formulating problems, collecting data, testing hypotheses, and concluding. Each stage of discovery learning teaches students about science process skills. During the learning process, students are given time to identify problems found during virtual lab work then look for answers to each problem and prove it based on theories obtained from books or online media. Then, the findings were discussed with the lecturer via virtual face using the Google Meet and Whatsapp Group applications. According to (Yusuf \& Widyaningsih, 2020), Online learning is also carried out to make it easier for students to access material and experience learning on platforms other than class. Discussions were also carried out in online classes, where students enthusiastically asked questions and discussed the material. Online discussions make it easier for students to get information because they immediately get the right answers through discussions between teachers and other students.

FKIP students of Universitas Darussalam Ambon are very enthusiastic in conducting discovery-based virtual laboratory learning. This can be proven by the enthusiasm of the students in the discussion. Basic science process skills such as observing, classifying, communicating, predicting, and concluding were seen during discussions. Student activeness during the learning process is due to having good learning motivation.(Damanik \& Anggaraeni, 2018; Suprihatin, 2015; Utari, 2016). The data shows an increase in science processing skills after discovery-based virtual laboratory learning. The increase in science process skills obtained based on pretest and post-test data is clarified and strengthened by the responses of responses to process skills in the form of observing, classifying, communicating, predicting, and concluding that students have. In general, students choose to agree with the statement items related to the science process skills indicators. As many as $81.82 \%$ of students said they liked making virtual observations and as many as $100 \%$ thought that virtual laboratories added knowledge in predicting and concluding an experiment. Then, a number of $90.91 \%$ stated that they were able to answer questions and express ideas and $90.91 \%$ of students found it easy to classify reactions after using discovery-based virtual laboratories.

The increase in science process skills in discovery-based virtual laboratory learning is due to the understanding that students gain becomes more meaningful. Students can more easily construct knowledge and experiences during the learning process (Matsun, Sunarno, \& Masykuri, 2016; Muchson, Munzil, Winarni, \& Agusningtyas, 2019). Science process skills possessed by students are needed in learning and applying a concept. This is done by the process of observing using the senses or relevant facts so that they can analyze the data to be grouped based on similarities and differences._In addition, students can also learn an event with other skills so that they can present the results in writing or discussion.

In addition, virtual laboratories provide opportunities for students to study independently and manage the time needed. Virtual laboratories can also increase understanding of scientific concepts more quickly. The use of animations and simulations containing sound and movement in a virtual laboratory can increase learning motivation in virtual lab activities and make chemistry learning more fun and interesting (Ambusaidi, 2018). R Syafrina (2018) states that virtual laboratories provide opportunities for students to enrich their learning experience. They can carry out experiments as if they were in a real laboratory. In addition, virtual labs also improve experimental skills, namely by manipulating materials and equipment, collecting data, and completing experimental processes in an interactive way (with an unlimited inventory). Assessment of the effectiveness of discovery-based virtual laboratory learning can be seen based on the N-Gain calculation. The calculation of NGain in this study uses two criteria, namely the N-Gain criteria in general and the criteria for effectiveness. Based on Table 7, the average increase in science process skills captured from the N-Gain calculation is in the high category with a value of 0.7 . In addition, the success rate of discovery-based virtual laboratory learning can be seen from the effectiveness of the learning carried out. Discovery-based virtual laboratory learning obtained an average percentage value of $66 \%$. Based on the effectiveness criteria, the average percentage is included in the moderately effective criteria. 
The effectiveness assessment obtained is relevant to the research conducted by (Achmad Lutfi, 2019) which states that the virtual laboratory phase is an inquiry-based teaching model that has proven effective in helping students construct concepts and develop more effective reasoning patterns. For abstract topics, the learning environment becomes interactive using virtual laboratory simulations where students become active in learning. Also provides opportunities for students to build and understand difficult concepts more easily. In addition, research by (Ambusaidi, 2018) stated that the virtual laboratory is effective in reducing the level of abstractness that usually occurs in students. Discovery-based virtual laboratory learning succeeded in improving students' science process skills. Through discovery-based virtual laboratory learning, process skills such as observing, classifying, communicating, predicting, and inferring are more easily developed. Thus, the learning carried out becomes more meaningful. The findings of this study greatly contribute to the development of education, especially in online learning. Through the application ofdiscovery-based virtual laboratory learning, practicum activities can still be carried out in distance learning. In addition, virtual labs are effective in improving the skills students have, one of which is science process skills. For direct learning (face-to-face), discovery-based virtual laboratories are recommended for practicum materials that use tools and materials that are not available, difficult to find and expensive. Meanwhile, for distance learning, discovery-based virtual laboratories can be used for all practicum materials. The findings of this study greatly contribute to the development of education, especially in online learning.

Discovery-based virtual laboratory learning on chemical equilibrium material can be repeated as desired so that the experience and understanding gained becomes more meaningful (Haryadi \& Pujiastuti, 2020). This is in line with opinion (Achmad Lutfi, 2019), which states that through the virtual laboratory students have the opportunity to repeat the experiment or deepen the desired experience. Virtual laboratories provide meaningful virtual experiences, presenting important concepts, principles and processes in learning. This research study shows that the visualization of phenomena through computer simulations can contribute to concept understanding. This is also supported by the results of research by (Yusuf \& Widyaningsih, 2018), who obtained excellent results in the use of virtual laboratory media so that science process skills and student perceptions developed. With discovery-based virtual laboratory learning, practicum activities can still be carried out in distance learning and are effective in improving student skills.

\section{Conclusion}

Discovery-based virtual laboratory learning is enough effective in improving Students' Science Process Skills. Discovery-based virtual laboratory learning has succeeded in improving students' Science Process Skills.

\section{References}

Abdjul, T., Ntobuo, N. E., \& Payu, C. (2019). Development of Virtual Laboratory-Based of Learning to Improve Physics Learning Outcomes of High School Students. Jurnal Pendidikan Fisika Indonesia, 15(2). https://doi.org/https://doi.org/10.15294/jpfi.v15i2.12367

Achmad Lutfi, S. (2019). Efektifitas Pelatihan Laboratorium Virtual Sebagai Media Pembelajaran Bagi Guru Kimia. 11(2), 303-309.

Ambusaidi, A. (2018). The Impact of Virtual Lab Learning Experiences on 9 th Grade Students 'Achievement and Their Attitudes Towards Science and Learning by Virtual Lab. 15(2). https://doi.org/10.12973/tused.10227a

Aşiksoy, G., \& Islek, D. (2017). The impact of the virtual laboratory on students' attitudes in a general physics laboratory. International Journal of Online Engineering, 13(4), 20-28. https://doi.org/10.3991/ijoe.v13i04.6811

Atmojo, S. E. (2012). Profil Keterampilan Proses Sains Dan Apresiasi Siswa Terhadap Profesi Pengrajin Tempe Dalam Pembelajaran IPA Berpendekatan Etnosains. Jurnal Pendidikan IPA Indonesia, 1(2). https://doi.org/https://doi.org/10.15294/jpii.v1i2.2128

Damanik, \& Anggaraeni. (2018). Hubungan Persepsi Keterampilan Mengajar Guru dengan Motivasi Belajar Siswa Akselerasi di Sekolah Menegah Atas Al-Azhar Medan. Analitika: Jurnal Magister Psikologi UMA, 10(2), 60-68. https://doi.org/https://doi.org/10.31289/analitika.v10i2.1788

Dewa, E., Maria Ursula Jawa Mukin, \& Oktavina Pandango. (2020). Pengaruh Pembelajaran Daring Berbantuan Laboratorium Virtual Terhadap Minat dan Hasil Belajar Kognitif Fisika. JARTIKA Jurnal Riset Teknologi Dan Inovasi Pendidikan, 3(2), 351-359. https://doi.org/10.36765/jartika.v3i2.288

Dewi, E. P., Suyatna, A., Abdurrahman, A., \& Ertikanto, C. (2017). Efektivitas Modul dengan Model Inkuiri 
untuk Menumbuhkan Keterampilan Proses Sains Siswa pada Materi Kalor. Tadris: Jurnal Keguruan Dan Ilmu Tarbiyah, 2(2), 105. https://doi.org/10.24042/tadris.v2i2.1901

Dewi, S. M., Gunawan, G., Harjono, A., Susilawati, S., \& Herayanti, L. (2020). Generative learning models assisted by virtual laboratory to improve mastery of student physics concept. Journal of Physics: Conference Series, 1521(2), 0-7. https://doi.org/10.1088/1742-6596/1521/2/022013

Ferdian, A., Maryam, S., \& Selamat, I. N. (2018). Analisis Kesiapan Belajar Siswa Kelas X Mipa Dalam Pembelajaran Kimia. Jurnal Pendidikan Kimia Undiksha, 2(1), 8. https://doi.org/10.23887/jjpk.v2i1.21177

Gunawan, Harjono, A., Hermansyah, \& Herayanti, L. (2019). Guided inquiry model through virtual laboratory to enhance students' science process skills on heat concept. Cakrawala Pendidikan, 38(2), 259-268. https://doi.org/10.21831/cp.v38i2.23345

Haryadi, R., \& Pujiastuti, H. (2020). PhET simulation software-based learning to improve science process skills. Journal of Physics: Conference Series, 1521(2). https://doi.org/10.1088/1742-6596/1521/2/022017

Hermansyah, H., Gunawan, G., \& Herayanti, L. (2017). Pengaruh Penggunaan Laboratorium Virtual Terhadap Penguasaan Konsep dan Kemampuan Berpikir Kreatif Siswa pada Materi Getaran dan Gelombang. Jurnal Pendidikan Fisika Dan Teknologi, 1(2), 97. https://doi.org/10.29303/jpft.v1i2.242

Jayadiningrat, M. G. (2017). Meningkatkan Kesiapan dan Hasil Belajar Siswa pada Pembelajaran Kimia dengan Pemberian Kuis di Awal Pembelajaran. E-Journal Pendidikan Kimia Indonesia, 1(1), 7-12. https://doi.org/http://dx.doi.org/10.23887/jpk.v1i1.12806

Khairudin, M., Triatmaja, A. K., Istanto, W. J., \& Azman, M. N. A. (2019). Mobile virtual reality to develop a virtual laboratorium for the subject of digital engineering. International Journal of Interactive Mobile Technologies, 13(4), 79-95. https://doi.org/10.3991/ijim.v13i04.10522

Lubis, \& Ikhsan. (2015). Pengembangan Media Pembelajaran Kimia Berbasis Android Untuk Meningkatkan Motivasi Belajar Dan Prestasi Kognitif Peserta Didik SMA. Jurnal Inovasi Pendidikan IPA, 1(2). https://doi.org/https://doi.org/10.21831/jipi.v1i2.7504.

Maksum, A. H. (2020). Analisis Penerapan Virtual Laboratorium Versus Reality Laboratorium. 17(2), 47-52.

Manikowati, Nf., \& Iskandar, D. (2018). Pengembangan Model Mobile Virtual Laboratorium Untuk Pembelajaran Praktikum Siswa Sma. Jurnal Kwangsan, 6(1), 23. https://doi.org/10.31800/jtp.kw.v6n1.p23--42

Marnita. (2013). Peningkatan Keterampilan Proses Sains Melalui Pembelajaran Kontekstual Pada Mahasiswa Semester I Materi Dinamika. Jurnal Pendidikan Fisika Indonesia, 9(1), 43-52. https://doi.org/10.15294/jpfi.v9i1.2579

Masril, Hidayat, Y. D. (2019). Penerapan Discovery Learning Berbantuan Virtual Laboratory Untuk Meningkatkan Kompetensi Fisika Siswa Sma. Jurnal Penelitian Pendidikan IPA ( JPPIPA ), 5(1), 18 25. https://doi.org/10.29303/jppipa.v5i1.160

Matsun, M., Sunarno, W., \& Masykuri, M. (2016). Penggunaan Laboratorium Riil Dan Virtuil Pada Pembelajaran Fisika Dengan Model Inkuiri Terbimbing Ditinjau Dari Kemampuan Matematis Dan Keterampilan Berpikir Kritis. Jurnal Pendidikan Fisika, 4(2). https://doi.org/https://doi.org/10.24127/jpf.v4i2.541

Muchson, M., Munzil, M., Winarni, B. E., \& Agusningtyas, D. (2019). Pengembangan Virtual Lab Berbasis Android Pada Materi Asam Basa Untuk Siswa SMA. Jurnal Pembelajaran Kimia, 4(1). https://doi.org/https://doi.org/10.17977/um026v4i12019p051

Nazalin, \& Muhtadi, A. (2016). Pengembangan Multimedia Interaktif Pembelajaran Kimia Pada Materi Hidrokarbon Untuk Siswa Kelas XI SMA. Jurnal Inovasi Teknologi Pendidikan, 3(2), 221-236. https://doi.org/https://doi.org/10.21831/jitp.v3i2.7359

Patandung, Y. (2017). Pengaruh model discovery learning terhadap peningkatan motivasi belajar IPA Siswa. Journal of Educational Science and Technology (EST), 3(1). https://doi.org/https://doi.org/10.26858/est.v3i1.3508.

Putrayasa, I. M., Syahruddin, \& Mergunayasa, I. G. (2014). Pengaruh Model Pembelajaran Discovery Learning Dan Minat Belajar Terhadap Hasil Belajar Ipa Siswa. Jurnal Mimbar PGSD Universitas Pendidikan 
Ganesha, 2(1). https://doi.org/http://dx.doi.org/10.23887/jjpgsd.v2i1.3087

R Syafrina, I. R. and G. Y. (2018). Analysis of chemical concepts as the basic of virtual laboratory development and process science skills in solubility and solubility product subject Analysis of chemical concepts as the basic of virtual laboratory development and process science skills in. Journal of Physics. https://doi.org/10.1088/1742-6596/1013/1/012092

Rahayuni, G. (2016). Hubungan Keterampilan Berpikir Kritis Dan Literasi Sains Pada Pembelajaran Ipa Terpadu Dengan Model Pbm Dan Stm. Jurnal Penelitian Dan Pembelajaran IPA, 2(2), 131. https://doi.org/10.30870/jppi.v2i2.926

Rina Mirdayanti, \& Murni. (2017). Kajian Penggunaan Laboratorium Virtual Berbasis Simulasi Sebagai Upaya Mengatasi Ketidak-Sediaan Laboratorium. Visipena Journal, 8(2), 323-330. https://doi.org/10.46244/visipena.v8i2.415

Rizal, A., Adam, R. I., \& Susilawati, S. (2018). Pengembangan Laboratorium Virtual Fisika Osilasi. JOIN: Jurnal Online Informatika, 3(1). https://doi.org/https://doi.org/10.15575/join.v3i1.140

Sari, P. I., Gunawan, G., \& Harjono, A. (2017). Penggunaan Discovery Learning Berbantuan Laboratorium Virtual pada Penguasaan Konsep Fisika Siswa. Jurnal Pendidikan Fisika Dan Teknologi, 2(4), 176. https://doi.org/10.29303/jpft.v2i4.310

Sunismi. (2015). Developing Guided Discovery Learning Materials Using Mathematics Mobile Learning Application As An Alternative Media For The Students Calculus II. Cakrawala Pendidikan, 34(5). https://doi.org/https://doi.org/10.21831/cp.v3i3.7340

Suprihatin, S. (2015). Upaya guru dalam meningkatkan motivasi belajar siswa. Jurnal Pendidikan Ekonomi UM Metro, 3(1), 72-82. https://doi.org/http://dx.doi.org/10.24127/ja.v3i1.144

Tatli, Z. (2010). Virtual laboratory applications in chemistry education. 9, 938-942. https://doi.org/10.1016/j.sbspro.2010.12.263

Utari, R. (2016). Kontribusi Motivasi Belajar Dan Kebiasaan Belajar Siswa Kelas 1 Teknik Audio Video Terhadap Hasil Belajar Pada Mata Diklat Pkdle Di Smk N 1 Padang. Jurnal Ilmiah Pendidikan Teknik Elektro, 1(oktober 2016), 108-114. https://doi.org/http://dx.doi.org/10.30870/volt.v1i2.2877

Wulandari, R. I., Herlita, \& Nurmiyati. (2020). Pengembangan media pembelajaran laboratorium virtual berbasis discovery learning materi sistem imun kelas XI MIPA. Media Penelitian Pendidikan: Jurnal Penelitian Dalam Bidang Pendidikan Dan Pengajaran, 14(1), 61-70.

Yusuf, I., \& Widyaningsih, S. W. (2018). Implementasi Pembelajaran Fisika Berbasis Laboratorium Virtual terhadap Keterampilan Proses Sains dan Persepsi Mahasiswa. Berkala Ilmiah Pendidikan Fisika, 6(1), 18. https://doi.org/10.20527/bipf.v6i1.4378

Yusuf, I., \& Widyaningsih, S. W. (2020). Implementing e-learning-based virtual laboratory media to students' metacognitive skills. International Journal of Emerging Technologies in Learning, 15(5), 63-74. https://doi.org/10.3991/ijet.v15i05.12029 